\title{
Analisis Kinerja Keuangan Pemerintah Daerah Kabupaten Tapanuli Tengah
}

\author{
Heri Faisal Harahap \\ Program Studi Magister Akuntansi, Universitas Andalas \\ Correspondence email: herifaisalharahap@gmail.com
}

\begin{abstract}
This research was aimed to know the financial performance of the Central Tapanuli regency government in 2016-2018. This research is quantitative descriptive. The research used secondary data in form of Financial Report of Central Tapanuli regency in 2016-2018. The analysis technique in this study calculates and analyzes the ratio of the decentralization level, regional financial dependence and effectiveness. The results of this study indicate that the financial performance of the Central Tapanuli Tengah Regional Government is generally said to be quite good, although the degree ratio is still relatively low, financial dependence on the Central / Provincial Government is still very high and the receipt of Regional Original Revenue does not reach the budgeted target. Central Tapanuli Regency Government to update the data of regional taxpayers, explore the potential of new sources of local revenue, and increase the socialization of tax benefits and user fees.
\end{abstract}

Keywords: Decentralitation Level, Local Financial Dependence, Financial Performance

\section{PENDAHULUAN}

Undang-Undang Nomor 17 Tahun 2003 tentang Keuangan Negara mengamanatkan Pemerintah untuk menyusun Laporan Keuangan Pemerintah Daerah yang terdiri atas Laporan Realisasi Anggaran, Laporan Arus Kas, Neraca, Catatan Atas Laporan Keuangan, Laporan SAL, Laporan Operasional, dan Laporan Perubahan Ekuitas. Laporan keuangan yang disusun dan disajikan oleh pemerintah daerah (pemda) merupakan laporan terstruktur yang menggambarkan posisi keuangan serta transaksi-transaksi keuangan dan nonkeuangan yang dilakukan setiap tahun. Laporan keuangan tersebut disusun dengan tujuan untuk menyajikan informasi mengenai posisi keuangan, realisasi anggaran, saldo anggaran lebih, arus kas, hasil operasi, dan perubahan ekuitas suatu entitas pelaporan yang diharapkan dapat memberikan manfaat bagi para pengguna dalam membuat dan mengevaluasi keputusan mengenai alokasi sumber daya (PSAP 01 Par: 9).

Salah satu aspek yang penting dalam pelaksanaan otonomi daerah dan desentralisasi yang diatur dengan hatihati adalah masalah pengelolaan keuangan daerah dan anggaran daerah untuk mewujudkan otonomi daerah dan desentralisasi yang luas, nyata, dan bertanggungjawab diperlukan manajemen keuangan daerah yang mampu mengawasi dan mengatur kebijakan keuangan daerah secara ekonomis, efisien, efektif, transparan, dan akuntabel (Mardiasmo, 2009). Keberhasilan otonomi daerah tidak terlepas dari kinerja pemerintah daerah dalam mengelola keuangannya secara tertib, taat pada peraturan perundangundangan, efisien, ekonomis, efektif, transparan dan bertanggung jawab. Penilaian kinerja pengelolaan keuangan dilakukan terhadap APBD yang dilakukan pemerintah daerah yang wajib menyampaikan laporan pertanggungjawaban keuangan daerahnya untuk dinilai apakah pemerintah daerah berhasil menjalankan tugasnya dengan baik atau tidak.

Mardiasmo (2009) menyatakan bahwa pengukuran kinerja dilakukan untuk memenuhi tiga maksud. Pertama, untuk membantu memperbaiki kinerja pemerintah. Kedua, untuk mengalokasikan sumber daya dan pembuatan keputusan. Ketiga, untuk mewujudkan pertanggungjawaban publik dan memperbaiki komunikasi kelembagaan. Kinerja merupakan sebuah pencapaian dari apa yang telah direncanakan oleh organisasi. Jika pencapaian sesuai dengan yang telah direncanakan, maka kinerja dari organisasi dapat dikatakan baik. Sebaliknya, jika pencapaian melebihi dari yang telah direncanakan dapat dikatakan kinerja organisasi tersebut sangat baik. Namun, apabila perencanaan tidak mencapai hasil yang diharapkan, maka kinerjanya dapat dikatakan buruk. Kinerja keuangan merupakan suatu alat ukur yang menggunakan indicator keuangan.

Kinerja Keuangan merupakan hasil realisasi pendapatan dan belanja yang disusun dan diukur berdasarkan basis akrual.Kinerja keuangan dapat disimpulkan merupakan gambaran kondisi keuangan perusahaan atau keuangan sebuah instansi yang dapat diukur dengan cara tertentu yang dapat berupa realisasi pendapatan dan belanja yang disusun berdasarkan basis akrual yang menghasilkan sebuah kesimpulan akan keberhasilan perusahaan atau instansi dalam mengelola keuangan (Darise, 2008). Analisis laporan keuangan adalah kegiatan untuk menginterpretasikan angka-angka dalam laporan keuangan dalam rangka menilai kinerja keuangan yang hasil analisis tersebut akan digunakan sebagai dasar pengambilan keputusan ekonomi, sosial, atau politik (Mahmudi, 2016). Analisis terhadap laporan keuangan dianggap menjadi alat manajerial yang penting untuk evaluasi kekuatan, dan kelemahan suatu 
perusahaan. Kondisi keuangan adalah konsep yang luas yang menggambarkan kesehatan keuangan pemerintah daerah (Turley, Robbins, \& McNena, 2015)

Penelitian yang dilakukan oleh Dewi \& Hafni (2017) menyimpulkan bahwa adanya kemandirian keuangan daerah Kabupaten Labuhan Batu Tahun Anggaran 2011-2013 dalam kategori rendah. Efektivitas keuangan daerah dalam kategori sangat efektif di tahun 2011 - 2012 dan tidak efektif di tahun 2013. Sedangkan efisiensi keuangan daerah berada pada kategori sangat efisien. Bila dilihat dari rasio belanja aktivitas / kecocokan pada periode 20112012, Kabupaten Labuhan Batu masih memprioritaskan pengeluaran rutin dibanding belanja modal. Selain pertumbuhan pendapatan daerah cenderung menurun dan negatif di tahun 2013, Pemkab Labuhan Batu memiliki kesempatan untuk melakukan pinjaman karena memiliki DSCR di atas 250\% setiap tahunnya. Selanjutnya, Sumual, Kalangi, \& Gerungai, (2017) menyimpulkan bahwa Selama tahun 2013-2016 Kota Tomohon hanya mendapatkan predikat sebagai Kota yang efektif karena banyak target yang telah dicapai, tapi untuk pertumbuhan kemandirian dan efesiensi Kota Tomohon belum memenuhi sesuai standar yang diinginkan.

Penelitian ini merupakan replikasi dari penelitian beberapa penelitian terdahulu yang mengukur kinerja pemerintah daerah menggunakan beberapa rasio diantaranya derajat desentralisasi, ketergantungan keuangan daerah, dan sebagainya. Perbedaan penelitian ini dengan penelitian terdahulu terletak pada objek penelitian yang digunakan, objek penelitian adalah Pemerintah Kabupaten Tapanuli Tengah. Alasan memilih Kabupaten Tapanuli Tengah, karena Kabupaten Tapanuli Tengah merupakan salah satu pemerintah daerah yang sudah berdiri lama dan memiliki letak geografis yang sangat strategis. Kondisi tersebut seharusnya menjadikan Kabupaten Tapanuli Tengah memiliki potensi keuangan daerah yang cukup tinggi dan diharapkan mampu memiliki kinerja keuangan yang baik dalam menunjang pembangunan daerah.

\section{METODE}

Jenis penelitian dalam riset ini adalah penelitian deskriptif kuantitatif. Penelitian deskriptif kuantitatif merupakan sebuah kerangka sistematis yang bertujuan memberikan jawaban terhadap suatu masalah dan/atau menggunakan tahap-tahap penelitian dengan pendekatan kuantitatif. Data yang digunakan didalam penelitian ini adalah data sekunder. Data sekunder tersebut adalah Laporan Keuangan Pemerintah Kabupaten Tapanuli Tengah Tahun 2016-2018. Tahap-tahap analisis laporan keuangan Pemerintah Kabupaten Tapanuli Tengah Tahun 2016 2018 yaitu menghitung rasio-rasio keuangan dan menganalisis serta mendeskripsikan hasil penghitungan rasio derajat desentralisasi, ketergantungan keuangan daerah, dan efektifitas. Rasio derajat desentralisasi dihitung berdasarkan perbanduingan antara jumlah Pendapatan Asli Daerah (PAD) dengan total Pendapatan Daerah. Semakin tinggi kontribusi PAD maka semakin tinggi kemampuan pemerintah daerah dalam penyelenggaraan desentralisasi. Rasio ini dirumuskan sebagai berikut:

Derajat Desentralisasi $=\frac{\text { PAD }}{\text { Total Pendapatan Daerah }} \times 100 \%$

Tabel 1

Kriteria Penilaian Derajat Desentralisasi

\begin{tabular}{|c|c|}
\hline Derajat Desentralisasi & Keterangan \\
\hline $0,00-10,00$ & Sangat Rendah \\
\hline $10,01-20,00$ & Rendah \\
\hline $20,01-40,00$ & Cukup \\
\hline $40,01-50,00$ & Tinggi \\
\hline$>50,00$ & Sangat Tinggi \\
\hline
\end{tabular}

Sumber : Kepmendagri No. 690.900.327, 1996

Rasio ketergantungan keuangan daerah dihitung dengan membandingkan jumlah pendapatan transfer yang diterima oleh penerimaan daerah dengan total penerimaan daerah. Semakin tinggi rasio ini maka semakin besar tingkat ketergantungan pemerintah daerah terhadap pemerintah pusat dan/atau pemerintah provinsi. Rasio ini dirumuskan sebagai berikut:

Rasio Ketergantungan Keuangan Daerah $=\frac{\text { Pendapatan Transfer }}{\text { Total Pendapatan Daerah }} \times 100 \%$ 
Tabel 2

Kriteria Penilaian Derajat Desentralisasi

\begin{tabular}{|c|c|}
\hline RKKD & Keterangan \\
\hline $0,00-10,00$ & Sangat Rendah \\
\hline $10,01-20,00$ & Rendah \\
\hline $20,01-40,00$ & Cukup \\
\hline $40,01-50,00$ & Tinggi \\
\hline$>50,00$ & Sangat Tinggi \\
\hline
\end{tabular}

Sumber : Kepmendagri No. 690.900.327, 1996

Rasio efektifitas ini dihitung dengan cara membandingkan realisasi penerimaan PAD dengan target penerimaan PAD (dianggarkan). Rasio ini dirumuskan sebagai berikut:

Efektifitas $=\frac{\text { Realisasi Penerimaan PAD }}{\text { Target Penerimaan PAD }} \times 100 \%$

Tabel 3

Nilai Efektifitas

\begin{tabular}{|c|c|}
\hline Efektifitas & Keterangan \\
\hline$>100 \%$ & Sangat Efektif \\
\hline $100 \%$ & Efektif \\
\hline $90 \%-99 \%$ & Cukup Efektif \\
\hline $75 \%-89 \%$ & Kurang Efektif \\
\hline$<75 \%$ & Tidak Efektif \\
\hline
\end{tabular}

Sumber : (Mahmudi, 2016)

\section{HASIL}

Kabupaten Tapanuli Tengah adalah salah satu dari 33 Kabupaten/Kota di Provinsi Sumatera Utara yang wilayahnya berada di Kawasan Pantai Barat Sumatera Utara dengan kondisi geografis berada pada posisi koordinat 1'11'00' - 2'22'00 LU dan 98'07' - 98'12' BT dengan luas wilayah 6.194,98 km2. Sebagian besar wilayah administrasi berada di Pulau Sumatera dan sebagian lagi merupakan 31 pulau-pulau kecil yang memiliki panorama alam yang sangat indah dengan panjang garis pantai $\pm 200 \mathrm{~km}$. Kabupaten Tapanuli Tengah dengan ibukotanya Pandan terdiri dari 20 Kecamatan dan 215 desa/kelurahan memiliki hamparan gunung, pantai, laut dan sungai yang dikenala dengan "GUPALA".

Rasio Derajat Desentralisasi adalah ukuran untuk menunjukkan tingkat kewenangan dan tanggung jawab yang diberikan pemerintah pusat kepada pemerintah daerah untuk melaksanakan pembangunan. Tingkat desentralisasi dihitung berdasarkan perbandingan antara jumlah Pendapatan Asli Daerah (PAD) dengan total penerimaan daerah.

Tabel 4

Perbandingan antara Jumlah Pendapatan Asli Daerah (PAD) dengan Total Penerimaan Daerah.

\begin{tabular}{lcrrr}
\hline \multicolumn{1}{c}{ Tahun } & PAD $(\mathbf{R p})$ & Total Pendapatan Daerah $(\mathbf{R p})$ & Derajat $(\%)$ & Ket \\
\hline 2016 & 71.758 .981 .995 & 1.069 .165 .690 .561 & 6,71 & Sangat Rendah \\
2017 & 72.710 .308 .590 & 1.094 .002 .131 .630 & 6,65 & Sangat Rendah \\
2018 & 76.660 .883 .410 & 1.216 .899 .572 .344 & 6,29 & Sangat Rendah \\
Rata-Rata & & & 6,55 & Sangat Rendah \\
\hline
\end{tabular}

Sumber : Data Diolah, 2019

Berdasarkan perhitungan diatas dapat dilihat bahwa tahun 2016 kinerja keuangan dari pengukuran derajat desentralisasi sebesar 6,71\% dan menurun pada tahun 2017 menjadi 6,65\% dan menurun terus pada tahun 2018 menjadi 6,29\%. Derajat desentralisasi Pemerintah Daerah Kabupaten Tapanuli Tengah tahun 2016 - 2018, menunjukkan penurunan dari tahun ke tahun. Rata-rata derajat desentralisasi dalam 3 tahun adalah sebesar 6,55\% dikategorikan rendah dengan merujuk Kepmendagri No. 690.900.327 Tahun 1996. Hal ini bertolak belakang dengan teori Mahmudi (2016) yang menyatakan semakin tinggi kontribusi PAD maka semakin tinggi kemampuan pemerintah daerah dalam penyelenggaraan desentralisasi.

Hasil ini menunjukkan bahwa pemerintah Kabupaten Tapanuli Tengah belum sepenuhnya mampu melepaskan diri dari bantuan pemerintah pusat dan provinsi untuk mendukung keuangan daerah dalam menyelenggarakan desenteralisasi dan pelayanan umum lebih baik meskipun proporsi Pendapatan Asli Daerah (PAD) yang dihasilkan terus mengalami peningkatan. Rasio Ketergantungan Keuangan Daerah ini dihitung dengan cara membandingkan jumlah pendapatan transfer yang diterima oleh penerimaan daerah dengan total penerimaan daerah. Berikut hasil perhitungannya: 
Tabel. 5

Rasio Ketergantungan Keuangan Daerah

\begin{tabular}{lrrrr}
\hline \multicolumn{1}{c}{ Tahun } & Pendapatan Transfer (Rp) & Total Pendapatan Daerah (Rp) & KKD (\%) & Ket \\
\hline 2016 & 1.009 .291 .823 .040 & 1.069 .165 .690 .561 & 94,40 & Sangat Tinggi \\
2017 & 1.028 .442 .721 .000 & 1.094 .002 .131 .630 & 94,01 & Sangat Tinggi \\
2018 & 1.140 .238 .688 .934 & 1.216 .899 .572 .344 & 93,70 & Sangat Tinggi \\
Rata-Rata & & & 94,03 & Sangat Tinggi \\
\hline
\end{tabular}

Sumber : Data Diolah, 2019

Dapat dilihat pada tabel diatas rasio di tahun 2016 sebesar 94,40\% mengalamin penurunan di tahun 2017 menjadi 94,01\% dan terus menurun di tahun 2018 menjadi 93,70\%. Rata-rata tingkat ketergantungan keuangan daerah Kabupaten Tapanuli Tengah selama periode tahun anggaran 2016-2018 adalah sebesar 94,03\%, sehingga diklasifikasikan menurut Kepmendagri No. 690.900.327 Tahun 1996 adalah sangat tinggi. Hal ini menunjukkan bahwa peran dari Pemerintah Pusat dan/atau Provinsi masih sangat dominan dalam membantu keuangan Pemerintah Kabupaten Tapanuli Tengah. Hasil penelitian ini tidak mendukung teori Halim \& Kusufi (2007) yang menyatakan bahwa semakin tinggi rasio ini, maka semakin besar tingkat ketergantungan pemerintah daerah terhadap pemerintah pusat atau pemerintah propinsi.

Rasio efektifitas dihitung dengan cara membandingkan realisasi penerimaan PAD dengan target penerimaan PAD. Perhitungan rasio ini tersaji pada tabel dibawah ini:

Tabel 6

Rasio Efektifitas

\begin{tabular}{lrrrl}
\hline Tahun & Realisasi Penerimaan PAD $(\mathbf{R p})$ & Target Penerimaan PAD $(\mathbf{R p})$ & Efektifitas $(\boldsymbol{\%})$ & Ket \\
\hline 2016 & 71.758 .981 .995 & 64.005 .291 .000 & 112,11 & Sangat Efektif \\
2017 & 72.710 .308 .590 & 82.981 .335 .879 & 87,62 & Kurang Efektif \\
2018 & 76.660 .883 .410 & 100.000 .000 .000 & 76,66 & Kurang Efektif \\
Rata-Rata & & & 92.13 & Cukup Efektif \\
\hline
\end{tabular}

Sumber : Data Diolah, 2019

Tabel 6 diatas dapat dilihat rasio efektivitas pada tahun 2016-2018 dikategorikan cukup efektif sebab realisasi penerimaan PAD mengalami penurunan. Pada tahun 2010 rasio efektifitasnya sebesar $112,11 \%$. Namun pada tahun 2011 menurun menjadi 87,62\%. Hal ini mengalami penurunan lagi di tahun 2018 menjadi 76,66\%. Rata-rata rasio efektifitas sebesar 92,13\% yang jika dihubungkan dengan kriteria yang dikemukakan oleh Mahmudi (2016) dinyatakan cukuk efektif. Penurunan rasio efektifitas setiap tahunnya terjadi karena tidak tercapainya penerimaan PAD yang disebabkan oleh kurangnya kesadaran masyarakat atau wajib pajak daerah dalam memenuhi kewajibannya perpajakannya salah satunya dengan tidak melaporkan jumlah pungutan pajak atas transaksi pada restoran/tempat hiburan dan sebagainya dengan nilai sesungguhnya. Hal ini tidak sesuai dengan teori yang diungkapkan oleh Halim (2004), semakin tinggi presentase rasio efektifitas menunjukkan semakin baik kemampuan daerahnya.

\section{SIMPULAN}

Berdasarkan hasil dan pembahasan penelitian, dapat ditarik kesimpulan kinerja keuangan Pemerintah Daerah Kabupaten Tapanuli Tengah secara umum dikatakan cukup baik, walaupun rasio derajat desentralisasi masih tergolong rendah, ketergantungan Pemerintah Pusat/Provinsi masih sangat tinggi serta penerimaan PAD tidak mencapai target yang dianggarkan. Penelitian ini diharapkan dapat menjadi bahan masukkan kepada Pemerintah Kabupaten Tapanuli Tengah agar dapat melakukan update data pengusaha-pengusaha yang menjadi wajib pajak daerah dengan cara melakukan kerja sama dengan intansi terkait seperti Badan Pusat Statistik, Dinas Penanaman Modal dan Perizinan Terpadu, Dinas Perdagangan, dan sebagainya. Sehingga penghitungan potensi PAD sesuai dengan jumlah potensi sesungguhnya.

Selanjutnya, Pemerintah Kabupaten Tapanuli Tengah dapat menggali potensi-potensi sumber pendapatan asli daerah yang baru dengan memanfaat sumber daya-sumber daya alam yang ada di Kabupaten Tapanuli Tengah, seperti pembukaan objek wisata baru yang dikelolah oleh Pemda bekerjasama dengan masyarakat sehingga dapat memberikan kontribusi terhadap penerimaan Pendapatan Asli Daerah salah satunya retribusi parkir. Selain itu, Pemerintah Kabupaten Tapanuli Tengah juga harus meningkatkan sosialisasi manfaat pajak dan retribusi kepada masyarakat. Sosialisasi dapat dilakukan dengan cara menurunkan personil di pasar-pasar atau tempat keramaian, sehingga mampu meningkatkan kesadaran masyarakat untuk membayar pajak dan retribusi. Penelitian ini memiliki keterbatasan dalam memperoleh data keuangan, peneliti memanfaatkan data yang terpublikasi pada situs www.djpk.kemenkeu.go.id sehingga peneliti tidak dapat menghitung beberapa rasio seperti Efisiensi dan Kemandirian Keuangan Daerah. Bagi peneliti selanjutnya agar dapat menambahkan rasio-rasio dalam mengukur kinerja keuangan 
dan juga dapat menambah objek penelitian sehingga mendapatkan perbandingan kinerja keuangan antara Pemerintah Daerah.

\section{DAFTAR PUSTAKA}

Ardila, I., \& Putri, A. A. (2015). Analisis Kinerja Keuangan dengan Pendekatan Value For Money Pada Pengadilan Negeri Tebing Tinggi. JRAB: Jurnal Riset Akuntansi \& Bisnis, 15(1).

Assidiqi, B. (2016). Analisis Kinerja Keuangan Anggaran Pendapatan dan Belanja Daerah (APBD) Kabupaten Klaten Tahun 2008-2012. Jurnal Profita: Kajian Ilmu Akuntansi, 4(5).

Bastian, I. (2010). Akuntansi Sektor Publik Suatu Pengantar Edisi Ketiga. Jakarta: Erlangga.

Darise, N. (2008). Akuntansi Keuangan Daerah (Akuntansi Sektor Publik). In Jakarta: Indeks.

Dewi, P. K., \& Hafni, N. (2017). Analisis Rasio Keuangan Untuk Mengukur Kinerja Keuangan Pemerintah Daerah Kabupaten Labuhan Batu Tahun Anggaran 2011-2013. KITABAH: Jurnal Akuntansi Dan Keuangan Syariah, $1(1)$.

Dora, J. (2017). Analisis Kinerja Keuangan Daerah Pemerintah Kota Yogyakarta Tahun 2010-2014. Skripsi.

Ferina, I. S., \& Arista, F. (2013). Penilaian Kinerja Dengan Menerapkan Indikator Value For Money Pada Kantor Pertanahan Kabupaten Musi Banyuasin Tahun 2009-2011. Jurnal Manajemen Dan Bisnis Sriwijaya, 11(1), 3350 .

Hakim, M. F. (2018). Analisis Kinerja Keuangan Pada Pemerintahdaerah Kabupaten Sleman Tahun Anggaran 20102016. Universitas Islam Indonesia. Yogyakarta.

Halim, A. (2004). Akuntansi Keuangan Daerah. Jakarta: Salemba Empat.

Halim, A. (2004). Manajemen Keuangan Daerah. Yogyakarta: UPP AMP YKPN.

Halim, A., \& Kusufi, M. S. (2007). Akuntansi Sektor Publik: Akuntansi Keuangan Daerah. Jakarta: Salemba Empat.

Kusumadewi, W. N., \& Ilat, V. (2016). Analisis Kinerja Keuangan pada Pemerintah Kabupaten Minahasa Utara Tahun 2012-2014. Jurnal EMBA: Jurnal Riset Ekonomi, Manajemen, Bisnis Dan Akuntansi, 4(1).

Mahmudi, M. (2010). Manajemen Kinerja Sektor Publik. Yogyakarta: UPP-STIM YKPN.

Mahmudi. (2016). Analisis Laporan Keuangan Pemerintah Daerah. UPP STIM YKPN.

Mardiasmo. (2009). Akuntansi Sektor Publik. In Yogyakarta: ANDI.

Mutiha, A. (2016). Analisis Kinerja Keuangan Pemerintah Daerah Kota Bogor Tahun Anggaran 2010-2014. Jurnal Vokasi Indonesia, 4(2).

Natalia, L., \& Astuti, T. D. (2016). Analisis Laporan Keuangan Dalam Mengukur Kinerja Keuangan Pada Pemerintah Kabupaten Sleman. Jurnal SosioHumaniora, 6(1).

Ndaparoka, D. S. R. (2018). Model Pengukuran Kemampuan Keuangan Daerah Melalui Kemandirian Fiskal Dan Derajat Ekonomi Untuk Meningkatkan Akuntabilitas Dan Transparansi Anggaran Pendapatan Dan Belanja (APBD) Pemerintah Kabupaten Sumba Barat. Jaka-Jurnal Jurusan Akuntasi, 3(1), 19-28.

Pemerintah Republik Indonesia. Peraturan Pemerintah Nomor 71 Tahun 2010 tentang Standar Akuntansi Pemerintah. _. Undang-Undang Nomor 17 Tahun 2003. , (2003).

Prayitno, B. (2017). Mengukur Kemampuan Keuangan Daerah Pemerintah Kota Semarang Dalam Pelaksanaan Otonomi Daerah Tahun 2013-2017. Jurnal Borneo Administrator, 13(3), 261-280.

Rofingatun, S., \& Kreuta, B. (2017). Analisis Kemampuan Keuangan Daerah Pemerintah Kabupaten Jayapura. Jurnal Kajian Ekonomi Dan Keuangan Daerah, 2(3).

Sinambela, E., \& Ana, K. R. A. P. R. (2016). Analisis Kinerja Anggaran Pendapatan Dan Belanja Daerah Pada Pemerintah Provinsi Sumatera Utara. JRAB: Jurnal Riset Akuntansi \& Bisnis, 16(1).

Sumual, C. D., Kalangi, L., \& Gerungai, N. Y. T. (2017). Analisis Pengukuran Kinerja Keuangan Pada Pemerintah Kota Tomohon. Jurnal Riset Akuntansi Going Concern, 12(2).

Syamsi, I. (1986). Pokok-pokok kebijaksanaan, perencanaan, pemrograman, dan penganggaran pembangunan tingkat nasional dan regional. Rajawali.

Turley, G., Robbins, G., \& McNena, S. (2015). A Framework To Measure The Financial Performance Of Local Governments. Local Government Studies, 41(3), 401-420. 